\title{
?
}

TI 2020-008/III

Tinbergen Institute Discussion Paper

\section{Financial Linkages and Sectoral Business Cycle Synchronization: Evidence from Europe}

Hannes Boehm ${ }^{1}$

Julia Schaumburg ${ }^{2}$

Lena Tonzer ${ }^{1,3}$

${ }^{1}$ Halle Institute for Economic Research

${ }^{2}$ Vrije Universiteit Amsterdam, Tinbergen Institute

3 Martin Luther University Halle-Wittenberg 
Tinbergen Institute is the graduate school and research institute in economics of Erasmus University Rotterdam, the University of Amsterdam and VU University Amsterdam.

Contact: discussionpapers@tinbergen.nl

More TI discussion papers can be downloaded at https://www.tinbergen.nl

Tinbergen Institute has two locations:

Tinbergen Institute Amsterdam

Gustav Mahlerplein 117

1082 MS Amsterdam

The Netherlands

Tel.: +31(0)205984580

Tinbergen Institute Rotterdam

Burg. Oudlaan 50

3062 PA Rotterdam

The Netherlands

Tel.: +31(0)10408 8900 


\title{
Financial Linkages and Sectoral Business Cycle Synchronization: Evidence from Europe*
}

\author{
Hannes Böhm ${ }^{\dagger}$ Julia Schaumburg ${ }^{\ddagger}$ Lena Tonzer ${ }^{\S}$
}

January 30,2020

\begin{abstract}
We analyze whether financial integration between countries leads to converging or diverging business cycles using a dynamic spatial model. Our model allows for contemporaneous spillovers of shocks to GDP growth between countries that are financially integrated and delivers a scalar measure of the spillover intensity at each point in time. For a financial network of ten European countries from 1996-2017, we find that the spillover effects are positive on average but much larger during periods of financial stress, pointing towards stronger business cycle synchronization. Dismantling GDP growth into value added growth of ten major industries, we observe that some sectors are strongly affected by positive spillovers (wholesale \& retail trade, industrial production), others only to a weaker degree (agriculture, construction, finance), while more nationally influenced industries show no evidence for significant spillover effects (public administration, arts \& entertainment, real estate).
\end{abstract}

JEL Classification: E32, F44, G10

Keywords: Financial Integration, Business Cycle Synchronization, Industry Dynamics, Spatial Model

\footnotetext{
${ }^{*}$ We thank Michael Barkholz, Franziska Bremus, Michela Rancan and Katheryn Russ for very helpful comments and discussions. Funding from the European Social Fund (ESF) of the European Commission is gratefully acknowledged by Lena Tonzer. Julia Schaumburg thanks the Dutch Science Foundation (NWO, grant VENI45115-022) for financial support. All errors are solely our own responsibility.

${ }^{\dagger}$ Halle Institute for Economic Research (IWH) E-mail: hannes.boehm@iwh-halle.de

${ }^{\ddagger}$ Vrije Universiteit Amsterdam E-mail: j.schaumburg@vu.nl

${ }^{\S}$ Halle Institute for Economic Research (IWH) and Martin Luther University Halle-Wittenberg E-mail: lena.tonzer@iwh-halle.de
} 


\section{Motivation}

Countries with stronger economic, cultural and political ties tend to have more synchronized output fluctuations. However, whether financial integration is one of such synchronizing factors for international business cycles is unresolved in the literature. On the one hand, Kose et al. (2003), Imbs (2006) and Morgan et al. (2004) find a positive relationship between financial integration and business cycle synchronization. On the other hand, results by Kalemli-Ozcan et al. (2013a) and Kalemli-Ozcan et al. (2013b) suggest that a higher degree of financial integration entails diverging patterns of economic activity. Cesa-Bianchi et al. (2019) argue that the nature of the shock, common (negative effect) or country-specific (positive effect), is what matters for synchronization.

We contribute to this literature, first, by assessing the effect of financial integration on economic activity not only among country pairs but across a multilateral network of directly and indirectly linked countries. More specifically, we use a flexible spatial model recently developed by Blasques et al. (2016) that combines time-varying matrices of economic distances, reflecting financial linkages, with a dynamic parameter approach. ${ }^{1}$ Our dynamic spatial model takes endogenous feedback and third-country effects into account. ${ }^{2}$ In this way, we retrieve a scalar intensity parameter that reflects the extent of positive or negative business cycle co-movement over time. This set-up allows us to compare the extent of spillovers during recessions and tranquil periods. A static spatial model, in comparison, would only reveal the net effect of positive and negative spillovers. As a second contribution, we dismantle the business cycle into its main industrial sectors, similarly to Schnabel and Seckinger (2015). As different industries can be exposed by different extents to shocks transmitted through financial links, this decomposition can give further insights on the conflicting results above. ${ }^{3}$

The analysis is based on a sample of 10 European countries over the period from 1996 to 2017 , for which gross domestic product (GDP) growth is dissected into the value-added by 10 industries. We find that financially more integrated countries tend to have on average positive business cycle synchronization. This finding means that shocks are transmitted across countries via their financial linkages resulting in positive co-movements of GDP growth. However,

\footnotetext{
${ }^{1}$ (Static) spatial models have recently become popular in the empirical finance literature, see, e.g., Tonzer (2015), Herskovic et al. (2017), and Denbee et al. (2018).

${ }^{2}$ Acemoglu et al. (2012), for example, emphasize the relevance of the network structure for spillover effects between sectors.

${ }^{3}$ International co-movement through firms in one country and their cross-border links is analyzed by, for example, Di Giovanni et al. (2018) and Kleinert et al. (2015).
} 
the effect depends crucially on time and industry. Positive synchronization effects of financial integration on GDP and industries with business-sensitive cycles such as industrial production or wholesale \& retail trade are much larger during crisis periods, as in Kalemli-Ozcan et al. (2013a). Other industries are subject to small positive synchronization effects which are, interestingly, almost constant over both recessions and normal times (agriculture, construction). Cycle synchronization of a few industries is not subject to any positive or negative spillover effect stemming from financial integration, suggesting that these industries (public administration, real estate, arts \& entertainment) are relatively closed-off and hardly affected by integrated financial markets. Therefore, time, industry-specification and feedback effects matter for the finance-business-cycle nexus.

The paper is structured as follows. In the next section, we describe the data and the empirical method. Results are presented in Section 3. The last section concludes the paper.

\section{Empirical Strategy}

\section{$2.1 \quad$ Data}

We proxy the degree of financial integration using data on direct bilateral cross-border claims of banks from the Bank for International Settlements (BIS). Similar to Kalemli-Ozcan et al. (2013a), Cesa-Bianchi et al. (2019) and many others, we make us of the locational banking statistics as they are well-suited for this task. Compared to the consolidated banking statistics, cross-border inter-office positions between banks of the same group are not netted out. Thus, the locational statistics deliver a clear picture on cross-border linkages with the potential of generating spillovers. From a theoretical perspective, this feature is important to consider as the activities of global banks matter for the transmission of shocks and effects on synchronization: Shocks in the real sector in one country should result in lower synchronization if global banks redirect their lending to unaffected countries. Shocks in the financial sector of some countries would induce global banks to retrench more globally, which in turn increases co-movement (Kalemli-Ozcan et al., 2013a).

For Europe, the BIS currently reports complete data for 10 countries since $1995 .{ }^{4}$ Based on this data, we can span a sizeable network of European countries. A snapshots of the network can be seen in Figure 1 for 2017Q4. The graph reveals that some countries are more strongly

\footnotetext{
${ }^{4}$ Belgium, Denmark, Finland, France, Germany, Ireland, Netherlands, Sweden, Switzerland, UK.
} 
interlinked than others, as reflected by the width of the links. The network overall shows a dense degree of interconnections. The sample period on which the estimations are based extends from 1996 until 2017 such that we can trace out whether the financial crisis starting in 2007/08 changes spillover dynamics permanently, or whether synchronization declines again, as one could hypothesize following the findings by Kalemli-Ozcan et al. (2013a) for the tranquil period before the financial crisis. In Tables 2 and 3, we show examples for the weighting matrix at different points in time. ${ }^{5}$

\section{[Insert Figure 1 here]}

[Insert Tables 2 and 3 here]

To capture the business cycle in a country and as our main dependent variable, we use quarterly GDP growth in constant prices drawn from the OECD. We then decompose GDP into quarterly gross value-added growth, also in constant prices, of 10 major industries downloaded from Eurostat. ${ }^{6}$ All growth rates are winsorized at the 1st and 99th percentile. Figure 2 shows the average pattern of GDP growth and sectoral growth over time. Obviously, a sharp decline can be detected for aggregate GDP growth as well as for most sectors following the financial crisis starting in $2007 / 08$. The growth path of some sectors closely resembles the one of aggregate GDP growth (e.g., industry (except construction) or wholesale \& retail trade) while some sectors have notably different dynamics.

\section{[Insert Figure 2 here]}

In Tables 4-6, we show that GDP growth rates across countries are correlated to different extents. However, we take a purely bilateral perspective in this case. In the estimations, we explicitly account for the fact that also indirect links can contribute to business cycle synchronization. Still, such simple descriptive statistics reveal important facts. On average, there is less evidence for negative co-movements. Supporting the findings by Kalemli-Ozcan et al. (2013a), during the crisis period (Table 5), correlations go up, which does apply to most country pairs but excludes those with Ireland. Comparing the pre- and post-crisis period, no general pattern emerges. Partially, correlations are lower, while for some other country pairs they are still at a

\footnotetext{
${ }^{5}$ In the empirical analysis, we use row-normalized versions of these matrices.

${ }^{6}$ Agriculture, forestry and fishing. Arts, entertainment, recreation and other services. Construction. Financial and insurance activities. Industry (except construction). Information and communication. Professional, scientific and tech activities. Public administration, deference, education, human health and social work. Real estate activities. Wholesale and retail trade, transport, accommodation and food.
} 
higher level (Tables 4 and 6). In sum, these patterns support the idea to control for time-varying spillover dynamics instead of taking a static view.

[Insert Tables 4-6 here]

To get a first glimpse on which sectors correlate most closely with aggregate growth, we show in Table 7 correlations between GDP growth and industrial sector growth rates. In line with the graphical evidence (Figure 2), correlations are highest between GDP growth and the industry (except construction) as well as the wholesale \& retail trade sectors. The lowest correlation emerges with the agricultural sector. These differences highlight that economies' aggregate growth paths can be determined by diverging sectoral developments such that taking a more granular and sectoral view can provide useful insights.

[Insert Table 7 here]

We require further national and global control variables that might affect the financebusiness-cycle nexus. On the country-level, we include quarterly growth rates of labor productivity, consumer confidence, labor force, gross fixed capital formation, government expenditure and credit to the non-financial sector (in percent of GDP). On the international level, we control for the quarterly change of the VIX and the Euro to U.S. Dollar exchange rate. More information on the variables can be found in the appendix. Summary statistics on the dependent and explanatory variables can be found in Table 8. We provide a correlation table between the dependent variable and the controls in Table 9 .

[Insert Tables 8-9 here]

\subsection{Method}

Our empirical methodology comes from the literature on time-varying spatial dependence as established by Blasques et al. (2016). Compared to the related literature, we do not calculate bilateral correlations between countries' GDP growth and explain those correlations. Instead, we model each country's GDP growth as a weighted function of all financially interlinked countries' GDP growth. The spatial modelling approach has the advantage that interdependencies between a large set of countries can simultaneously be taken into account, and that the possibility of contemporaneous spillovers of shocks is incorporated. 
Spatial models require the specification of a spatial weights matrix, which is typically chosen as a function of physical or economic distances between units. In our case, economic distance is defined by the cross-border bank claims two countries hold towards another, which is a measure of the degree of financial integration. We use a spatial lag model, which implies that each country's dependent variable may react to shocks to both the regressors and the disturbances of neighboring countries. Third-country and feedback effects are automatically taken into account. Additionally, we employ a time-varying spatial dependence parameter approach as suggested in Blasques et al. (2016). In this way, the magnitude of cross-sectional spillovers transmitted by financial integration can vary over time, allowing us to compare the effects during different stages of the economic and financial cycle.

The score-driven spatial lag model is given by

$$
y_{t}=\rho_{t} W_{t} y_{t}+X_{t} \beta+e_{t}, \quad e_{t} \sim p_{e}(0 ; \Sigma, \nu), \quad t=1, \ldots, T
$$

where $y_{t}$ denotes an $N \times 1$ - vector of country-specific growth rates of GDP or industrial value added at time $t . \beta=\left(\beta_{1}, \ldots, \beta_{M}\right)^{\prime}$ is a vector of unknown coefficients, $X_{t}$ is a matrix of countryspecific and international regressors ${ }^{7}$ and $\Sigma$ is a positive definite covariance matrix. $p_{e}$ denotes the density of the vector of disturbances $e_{t}$. We consider normally and Student's $t$-distributed disturbances. In the case of Student's $t$-distributed disturbances, $p_{e}$ also depends on a degrees of freedom parameter $\nu$.

The matrix $W_{t}$ reflects the degree of financial integration between countries at time $t$ and is assumed to be weakly exogenous. ${ }^{8}$ The scalar spatial dependence parameter $\rho_{t}$ measures the intensity of cross-country shock spillovers of real output, that are induced by financial links. To ensure stability, we specifiy $\rho_{t}=h\left(f_{t}\right)$ where $h(\cdot)$ is a monotone transformation such that $\rho_{t} \in(-1,1)$. To describe the dynamics of $f_{t}$, we adopt the autoregressive score framework of Creal et al. $(2011,2013)$ and Harvey $(2013) .{ }^{9}$ The score framework centers around the use of the scaled score of the conditional density $p_{e}$ to drive the time-variation in $f_{t}$. The updating equation for $f_{t}$ is given by

$$
f_{t+1}=\omega+A s_{t}+B f_{t},
$$

\footnotetext{
${ }^{7}$ The dependent variable and the explanatory variables are demeaned to control for country fixed effects. We control for time-varying dynamics affecting all countries alike by including global controls.

${ }^{8}$ See the data appendix for an example of a matrix for one point in time (Tables 2-3).

${ }^{9}$ See www.gasmodel.com for a more complete compilation of papers.
} 
where $\omega, A$, and $B$ are fixed unknown parameters, and $s_{t}=S_{t} \nabla_{t}$ is the scaled score function, which serves as innovation term for the time-varying parameter. ${ }^{10}$

The spatial dependence coefficient $\rho_{t}$ may be interpreted as an indicator of the degree of business cycle synchronization driven by financial links: A positive coefficient would reveal evidence for business cycle synchronization, while a negative coefficient would point towards desynchronization. Importantly, the modeling approach takes into account that in highly integrated markets, business cycle synchronization does not only occur between two countries in isolation. For example, shocks to country A can spill over to the directly linked country B but also affect country $\mathrm{C}$, which has in turn financial links to country B.

Instead of imposing a particular model specification ex ante, we determine empirically whether GDP growth rates and industrial value added are indeed driven by shock spillovers from other countries. In particular, we estimate three versions of the model, each assuming either normally or Student's $t$ distributed disturbances: (1) a baseline specification without any spillovers, i.e. $\rho_{t}=0, t=1, \ldots, T,(2)$ a static version with $\rho_{t}=\rho, \forall t$ and (3) the dynamic specification given in equation (1). Model selection is conducted using the Akaike Information Criterion corrected for small sample sizes (AICc).

\section{Estimation results}

\subsection{Results for overall output fluctuations (GDP)}

Table 10 shows the results using quarterly GDP growth as the dependent variable for different specifications of the spatial model. Columns (1) and (2) report results obtained using a model without spillovers, columns (3) and (4) show findings allowing for spillovers with a static dependence coefficient, and columns (5) and (6) display results for a model with time-varying spillover effects of financial integration on GDP growth. The errors are assumed to be either normally or $t$-distributed. Values of the AICc indicate that the data favor the model using time-varying spillover effects and a $t$-distribution with the AICc being lower by 93 points than the no spillover model and by 20 points compared to the static model. Allowing for time-varying spillovers as introduced in Section 2.2 therefore seems to be the most appropriate way to measure the effect of financial integration on output fluctuations.

\footnotetext{
${ }^{10}$ The complete model specification including the expressions for $s_{t}$ in the case of normal and Student's $t$ distributed disturbances are given in the online appendix.
} 
[Insert Table 10 here]

Turning to the coefficients, we find strong evidence for spatial dependence both in the static and the dynamic model, with $\rho$ as well as $A$ and $B$, the parameters entering the dynamic updating equation (2), being large and statistically highly significant. This result thus supports that, from a regional perspective, business cycles should not be considered in isolation in financially integrated countries as dynamics can propagate via financial links towards a country's own GDP growth.

All other coefficients enter with largely expected signs in all models. For example, productivity growth enters with a positive and economically and statistically highly significant coefficient. In our preferred specification, that features dynamic spillovers and $t$-distributed errors (column (6)), we obtain that rising consumer confidence, labor force, government expenditure and a depreciating Euro towards the U.S. Dollar are positively and statistically significantly associated with higher GDP growth. Gross fixed capital formation growth also enters with a positive coefficient that is, however, not significant on a $10 \%$ level. Changes in the volatility index VIX enter with a positive sign while increasing credit ratios carry a negative sign, but both coefficients are statistically insignificant. ${ }^{11}$

Having established that dynamic spillover effects from financial integration matter for European countries' GDP growth, we now turn to the evolution of the spillover intensity parameter over time, see Figure 3. We observe a strong cyclical component. While the parameter is positive on average, it peaks during times of financial stress, in particular the dotcom bubble (around 2000), the financial crisis (around 2008) and the European debt crisis (2011-2013). In calmer times (mid 1990s or mid 2000s), the spillover strength is lower, whereas in the recent time period (mid 2010s) characterized by financial disintegration, the spillover strength even becomes negative. This result is broadly in line with Kalemli-Ozcan et al. (2013a) who identify that financial integration has stronger effects on business cycle synchronization in times of crisis.

[Insert Figure 3 here]

\subsection{Results for industrial output flucations}

We now apply the analysis to individual industrial sectors. This dissection can shed light on the components that drive the aggregated effects on GDP we discussed in the previous section. Note

\footnotetext{
${ }^{11}$ The results are robust towards employing an alternative model specification using OLS regressions with country and year fixed effects.
} 
that certain sectors are highly sensitive towards the business cycle, such as industrial output or wholesale and retail trade. For these sectors, we therefore expect similar patterns, both in terms of the best-fitting model and for the graph of the time-varying spillovers, compared to GDP growth. For other industrial sectors, we do not expect the same sensitivity towards growth shocks from other countries. An example is public administration, a largely nationally determined sector that should not vary much with business cycle spillovers due to international financial integration.

As before, we estimate six versions of each model (no spillovers, constant and dynamic dependence parameter, and both normal and $t$-errors), but for brevity, we only show the respective best model in Table 11 according to the AICc. ${ }^{12}$ The results in Table 11 can be summarized as follows. Time-varying spillover dynamics fit the data best for four out of ten industrial sectors: industry (excluding construction); information \& communication; professional, scientific and tech activities; wholesale \& retail trade. Four different sectors show the best fit for a model that allows for spillovers, which are, however, driven by a constant instead of a time-varying parameter: agriculture, forestry and fishing; arts, entertainment, recreation and other services; construction; financial and insurance activities. Finally, there are two cases, public administration and real estate, for which we do not find evidence for any spatial dependence.

[Insert Table 11 here]

Figure 4 depicts the time-varying dependence parameters for the four industries, for which the time-varying model turned out to be the best fit.

\section{[Insert Figure 4 here]}

The patterns of three industrial sectors' spillover parameters are similar to the graph for GDP, see Figure 3. The resemblance is most obvious for the wholesale \& retail trade sector, but it is also present for industry (excluding construction) as well as for professional, scientific and tech activities. ${ }^{13}$ These three industries have in common that they strongly depend on the current business cycle, making them similarly affected towards spillovers from financial integration as overall GDP. Hence, both our estimation results and the graphs suggest that

\footnotetext{
${ }^{12}$ In the online appendix, we provide tables containing results from all model specifications for each sector (Tables A1-A10).

${ }^{13}$ This sector comprises mostly legal, management or engineering activities, see: https://ec.europa. eu/eurostat/statistics-explained/index.php?title=File:F1_Sectoral_analysis_of_Professional, _scientific_and_technical_activities_(NACE_Section_M),_EU-28,_2016.png.
} 
interlinked countries specializing in these sectors are very likely to face a higher extent of business cycle synchronization, which relates to the results by Imbs (2004).

We also observe strong, time-varying spillovers across European countries' IT sectors (information \& communication). However, the pattern differs from the ones for the other three sectors. Our interpretation of this finding is that IT sectors do face growth spillovers driven by financial interconnections, but in a more idiosyncratic way, potentially reflecting the more volatile and disruptive nature of this sector.

There is no evidence for spatial dependence for the public administration sector. ${ }^{14}$ Similar results can be observed for the sector arts \& entertainment and the real estate sector, which makes sense as both are largely nationally influenced. In the estimation results, these sectors showed the best fit for a no-spillover or static spillover model, suggesting that they are largely unaffected by spillover effects stemming from financial market integration.

We observe positive but rather small spillover effects for the agricultural, construction and financial sectors. Furthermore, the data for all these sectors favor a model with static spillover coefficient. ${ }^{15}$ These results may indicate that the mentioned sectors are exposed to spillovers due to financial integration, but not as prime candidates or in a cyclical manner.

\section{Conclusions}

Whether financial integration between countries leads to diverging or converging patterns of GDP growth is still not fully resolved in the literature. We shed new light on this issue by modeling a group of financially developed European countries as a financial network, thereby extending the pure bilateral framework used in the literature, and taking dynamic feedback effects within the network into account. We arrive at two major results.

First, spillover effects via the channel of financial integration on business cycles vary over time and are much stronger during periods of financial turmoil. Second, business-sensitive sectors like industrial production, wholesale \& retail trade, or professional, scientific \& tech activities are strongly exposed to spillover effects from financial integration, with time-variation following a similar cyclical pattern as for overall GDP. Industrial sectors such as agriculture, construction or finance also feature positive spillover effects, but are less affected, and the spillover intensity

\footnotetext{
${ }^{14}$ This is also visible in the respective plot in the online appendix, where the spillover parameter fluctuates around zero (Figure A1).

${ }^{15}$ The time-varying spillover coefficients are also almost constant throughout our estimation period, as can be seen in the online appendix.
} 
does not vary over time. Nationally influenced sectors such as public administration, arts \& entertainment and real estate are not subject to relevant spillovers, positive or negative, due to financial integration.

Our results bear important policy implications. As we consistently find evidence for positive spillover dynamics across European countries and over time, our results show that in a densely financially integrated network of countries, business cycles are co-moving. Consequently, focusing only on national approaches to stabilize business cycles is likely to have limited effects, especially during times of crisis. In contrast, national measures should be accompanied by supranational actions mitigating spillovers of shocks via cross-border links among banking system, which supports policy measures such as the establishment of a European Banking Union. Furthermore, we show that industries are exposed to growth spillovers at different extents. This finding implies that in order to evaluate the exposure of a country's economy to business cycle synchronization and to mitigate negative effects during crisis times, sectoral specializations have to be taken into account. Only then can policy rescue programs be more effectively designed to support the sectors in distress. 


\section{$5 \quad$ References}

Acemoglu, D., Carvalho, V. M., Ozdaglar, A., and Tahbaz-Salehi, A. (2012). The network origins of aggregate fluctuations. Econometrica, 80(5):1977-2016.

Blasques, F., Koopman, S. J., Lucas, A., and Schaumburg, J. (2016). Spillover dynamics for systemic risk measurement using spatial financial time series models. Journal of Econometrics, 195(2):211-223.

Cesa-Bianchi, A., Imbs, J., and Saleheen, J. (2019). Finance and synchronization. Journal of International Economics, 116:74-87.

Creal, D., Koopman, S. J., and Lucas, A. (2011). A dynamic multivariate heavy-tailed model for time-varying volatilities and correlations. Journal of Business and Economic Statistics, $29(4): 552-563$.

Creal, D., Koopman, S. J., and Lucas, A. (2013). Generalized autoregressive score models with applications. Journal of Applied Econometrics, 28:777-795.

Denbee, E., Julliard, C., Li, Y., and Yuan, K. (2018). Network risk and key players: A structural analysis of interbank liquidity. Fisher College of Business Working Paper No. 2018-03-011.

Di Giovanni, J., Levchenko, A. A., and Mejean, I. (2018). The micro origins of international business-cycle comovement. American Economic Review, 108(1):82-108.

Harvey, A. C. (2013). Dynamic Models for Volatility and Heavy Tails. Econometric Society Monographs, Cambridge University Press.

Herskovic, B., Kelly, B., Lustig, H., and Nieuwerburgh, S. V. (2017). Firm volatility in granular networks. Fama-Miller Working Paper August 2017.

Imbs, J. (2004). Trade, finance, specialization, and synchronization. The Review of Economics and Statistics, 86(3):723-734.

Imbs, J. (2006). The real effects of financial integration. Journal of International Economics, $68(2): 296-324$.

Kalemli-Ozcan, S., Papaioannou, E., and Perri, F. (2013a). Global banks and crisis transmission. Journal of International Economics, 89(2):495-510.

Kalemli-Ozcan, S., Papaioannou, E., and Peydró, J.-L. (2013b). Financial regulation, financial globalization, and the synchronization of economic activity. The Journal of Finance, 68(3):1179-1228.

Kleinert, J., Martin, J., and Toubal, F. (2015). The Few Leading the Many: Foreign Affiliates and Business Cycle Comovement. American Economic Journal: Macroeconomics, 7(4):13459.

Kose, A. M., Prasad, E. S., and Terrones, M. E. (2003). How does globalization affect the synchronization of business cycles? American Economic Review, 93(2):57-62.

Morgan, D. P., Rime, B., and Strahan, P. E. (2004). Bank Integration and State Business Cycles. The Quarterly Journal of Economics, 119(4):1555-1584.

Schnabel, I. and Seckinger, C. (2015). Financial Fragmentation and Economic Growth in Europe. CEPR Discussion Papers 10805, C.E.P.R. Discussion Papers.

Tonzer, L. (2015). Cross-border interbank networks, banking risk and contagion. Journal of Financial Stability, 18:19-32. 


\section{$6 \quad$ Tables and Figures}

Table 1: Description and sources of variables

\begin{tabular}{|c|c|c|}
\hline Variable & Description & Source \\
\hline \multicolumn{3}{|l|}{ Dependent Variables } \\
\hline$\Delta \mathrm{GDP}$ & $\begin{array}{l}\text { Quarter-to-quarter growth rate of GDP } \\
\text { in constant } 2010 \text { prices, seasonally adjusted. }\end{array}$ & OECD \\
\hline$\Delta$ Industry Sector & $\begin{array}{l}\text { Quarter-to-quarter growth rates of } \\
\text { gross value added in constant } 2010 \\
\text { prices, season and calendar adjusted. } \\
\text { Industries according to Eurostat's A*10 industry } \\
\text { breakdown are: } \\
\text { Agriculture, forestry and fishing. } \\
\text { Arts, entertainment, recreation and other services. } \\
\text { Construction. } \\
\text { Financial and insurance activities. } \\
\text { Industry (except construction). } \\
\text { Information and communication. } \\
\text { Professional, scientific and tech activities. } \\
\text { Public administration, defence, education, human } \\
\text { health and social work. } \\
\text { Real estate activities. } \\
\text { Wholesale and retail trade, transport, } \\
\text { accommodation and food. }\end{array}$ & Eurostat \\
\hline \multicolumn{3}{|l|}{ Spatial Matrix } \\
\hline $\begin{array}{l}\text { Spatial Matrix } \\
\text { Weights }\end{array}$ & $\begin{array}{l}\text { BIS locational banking statistics, total claims of all reporting } \\
\text { banks (in all currencies and instruments) towards all sectors } \\
\text { in counterparty country. }\end{array}$ & BIS \\
\hline \multicolumn{3}{|l|}{ Control Variables } \\
\hline$\Delta$ Productivity & Labour productivity, growth rate, seasonally adjusted. & OECD \\
\hline$\Delta$ Consumer Confidence & $\begin{array}{l}\text { Consumer confidence indicator, growth rate, } \\
\text { seasonally adjusted. }\end{array}$ & OECD \\
\hline $\begin{array}{l}\Delta \text { Gross Fixed Capital } \\
\text { Formation (GFCF) }\end{array}$ & $\begin{array}{l}\text { Gross fixed capital formation, growth rate, } \\
\text { constant prices, seasonally adjusted. }\end{array}$ & OECD \\
\hline$\Delta$ Labour Force & Labour force, growth rate, seasonally adjusted. & OECD \\
\hline $\begin{array}{l}\Delta \text { Government } \\
\text { Expenditure }\end{array}$ & $\begin{array}{l}\text { Government final consumption expenditure, growth rate, } \\
\text { constant prices, seasonally adjusted. }\end{array}$ & OECD \\
\hline $\begin{array}{l}\Delta \text { Credit to } \\
\text { Non-Financial } \\
\text { Sector }\end{array}$ & $\begin{array}{l}\text { Credit to private non-financial sector, growth rate, } \\
\text { provided by all sectors, in percent of GDP. }\end{array}$ & BIS \\
\hline$\Delta$ VIX & Volatility VIX, growth rate. & $\mathrm{CBOE}$ \\
\hline $\begin{array}{l}\Delta \text { Euro-to-Dollar } \\
\text { Exchange Rate }\end{array}$ & Euro to U.S. Dollar exchange rate, growth rate. & Thomson Reuters \\
\hline
\end{tabular}


Table 2: Network matrix of banking systems' cross-border claims for 1996:Q1

\begin{tabular}{lcccccccccc}
\hline \hline & Belgium & Denmark & Finland & France & Germany & Ireland & Netherlands & Sweden & Switzerland & UK \\
\hline Belgium & & 1374 & 1526 & 28657 & 10514 & 5974 & 14907 & 3855 & 5348 & 47685 \\
Denmark & 2038 & & 1341 & 3136 & 1533 & 2533 & 850 & 5507 & 969 & 15507 \\
Finland & 617 & 470 & & 786 & 372 & 17 & 316 & 3914 & 233 & 3916 \\
France & 29439 & 6380 & 2241 & & 39688 & 3529 & 15750 & 4918 & 16766 & 146083 \\
Germany & 13509 & 5466 & 4576 & 28134 & & 11273 & 21636 & 6820 & 13429 & 116563 \\
Ireland & 1126 & 650 & 794 & 2400 & 8621 & & 1647 & 1474 & 479 & 12090 \\
Netherlands & 21963 & 2280 & 703 & 14368 & 21862 & 6041 & & 3768 & 7602 & 40884 \\
Sweden & 1351 & 1594 & 1656 & 897 & 1746 & 277 & 2117 & & 778 & 17531 \\
Switzerland & 36673 & 1475 & 927 & 31597 & 23261 & 1868 & 34426 & 2498 & 39088 & 173198 \\
UK & 41960 & 9614 & 9224 & 96405 & 161291 & 17703 & 33092 & 25833 & 3908 & \\
\hline
\end{tabular}

Notes: This table shows the network matrix based on BIS locational banking statistics for 1996:Q1. Data on a country's banking system claims (from row-country towards column-country) in millions of US dollars is depicted.

Table 3: Network matrix of banking systems' cross-border claims for 2017:Q4

\begin{tabular}{lcccccccccc}
\hline \hline & Belgium & Denmark & Finland & France & Germany & Ireland & Netherlands & Sweden & Switzerland & UK \\
\hline Belgium & & 2423 & 1150 & 71463 & 52457 & 20012 & 72993 & 2444 & 14870 & 72486 \\
Denmark & 1998 & & 7661 & 12851 & 47964 & 2114 & 3039 & 83375 & 3520 & 31498 \\
Finland & 1318 & 12614 & & 5858 & 8170 & 496 & 2583 & 21551 & 143 & 8985 \\
France & 122957 & 10260 & 7133 & & 118875 & 67037 & 108142 & 18416 & 76632 & 372761 \\
Germany & 36694 & 20771 & 22328 & 216641 & & 34132 & 173043 & 41449 & 79548 & 322777 \\
Ireland & 6312 & 4006 & 908 & 19655 & 16158 & & 26158 & 2445 & 2416 & 94892 \\
Netherlands & 61170 & 4268 & 10620 & 85493 & 81552 & & & 6724 & 29611 & 318205 \\
Sweden & 2930 & 104404 & 96840 & 12968 & 29685 & 1102 & 9286 & & 5897 & 64214 \\
Switzerland & 9654 & 5510 & 1109 & 57596 & 49264 & 8158 & 23053 & 4374 & 199079 & 148994 \\
UK & 56175 & 22008 & 17182 & 507496 & 439557 & 163186 & 315718 & 44461 & 199079 & \\
\hline
\end{tabular}

Notes: This table shows the network matrix based on BIS locational banking statistics for 2017:Q4. Data on a country's banking system claims (from row-country towards column-country) in millions of US dollars is depicted. 
Table 4: Correlation of $\Delta$ GDP between countries (pre-crisis)

\begin{tabular}{|c|c|c|c|c|c|c|c|c|c|c|}
\hline & Belgium & Denmark & Finland & France & Germany & Ireland & Netherlands & Sweden & Switzerland & UK \\
\hline Belgium & 1.000 & & & & & & & & & \\
\hline Denmark & 0.175 & 1.000 & & & & & & & & \\
\hline Finland & 0.214 & -0.141 & 1.000 & & & & & & & \\
\hline France & 0.432 & 0.303 & 0.315 & 1.000 & & & & & & \\
\hline Germany & 0.365 & 0.274 & 0.133 & 0.368 & 1.000 & & & & & \\
\hline Ireland & 0.339 & 0.234 & 0.144 & 0.176 & 0.095 & 1.000 & & & & \\
\hline Netherlands & 0.425 & 0.424 & 0.136 & 0.507 & 0.448 & 0.218 & 1.000 & & & \\
\hline Sweden & 0.222 & 0.121 & 0.141 & 0.411 & 0.094 & 0.074 & 0.348 & 1.000 & & \\
\hline Switzerland & 0.462 & 0.060 & 0.233 & 0.469 & 0.345 & 0.202 & 0.348 & 0.307 & 1.000 & \\
\hline UK & 0.006 & -0.064 & -0.009 & 0.104 & -0.007 & 0.214 & 0.082 & -0.005 & 0.160 & 1.000 \\
\hline
\end{tabular}

Table 5: Correlation of $\Delta$ GDP between countries (during the crisis)

\begin{tabular}{|c|c|c|c|c|c|c|c|c|c|c|}
\hline & Belgium & Denmark & Finland & France & Germany & Ireland & Netherlands & Sweden & Switzerland & UK \\
\hline Belgium & 1.000 & & & & & & & & & \\
\hline Denmark & 0.846 & 1.000 & & & & & & & & \\
\hline Finland & 0.830 & 0.743 & 1.000 & & & & & & & \\
\hline France & 0.889 & 0.751 & 0.849 & 1.000 & & & & & & \\
\hline Germany & 0.918 & 0.752 & 0.875 & 0.991 & 1.000 & & & & & \\
\hline Ireland & 0.152 & -0.081 & 0.148 & 0.137 & 0.109 & 1.000 & & & & \\
\hline Netherlands & 0.721 & 0.546 & 0.811 & 0.860 & 0.873 & -0.111 & 1.000 & & & \\
\hline Sweden & 0.764 & 0.510 & 0.794 & 0.748 & 0.762 & 0.433 & 0.780 & 1.000 & & \\
\hline Switzerland & 0.925 & 0.775 & 0.874 & 0.860 & 0.912 & 0.005 & 0.811 & 0.761 & 1.000 & \\
\hline UK & 0.922 & 0.680 & 0.685 & 0.891 & 0.907 & 0.139 & 0.684 & 0.619 & 0.805 & 1.000 \\
\hline
\end{tabular}

Table 6: Correlation of $\Delta$ GDP between countries (post-crisis)

\begin{tabular}{|c|c|c|c|c|c|c|c|c|c|c|}
\hline & Belgium & Denmark & Finland & France & Germany & Ireland & Netherlands & Sweden & Switzerland & UK \\
\hline Belgium & 1.000 & & & & & & & & & \\
\hline Denmark & 0.369 & 1.000 & & & & & & & & \\
\hline Finland & 0.551 & 0.188 & 1.000 & & & & & & & \\
\hline France & 0.399 & 0.018 & 0.423 & 1.000 & & & & & & \\
\hline Germany & 0.626 & 0.082 & 0.450 & 0.564 & 1.000 & & & & & \\
\hline Ireland & 0.181 & -0.318 & -0.140 & 0.381 & 0.205 & 1.000 & & & & \\
\hline Netherlands & 0.338 & 0.026 & 0.446 & 0.441 & 0.327 & 0.265 & 1.000 & & & \\
\hline Sweden & 0.062 & -0.229 & -0.038 & -0.118 & 0.008 & 0.094 & 0.534 & 1.000 & & \\
\hline Switzerland & 0.088 & 0.072 & 0.136 & 0.187 & 0.302 & 0.170 & 0.134 & -0.102 & 1.000 & \\
\hline UK & 0.137 & 0.045 & 0.192 & 0.132 & 0.325 & 0.155 & 0.189 & 0.237 & 0.220 & 1.000 \\
\hline
\end{tabular}

Notes: This table shows correlations of GDP growth rates ( $\Delta$ GDP) between countries after 2009 (post-crisis). GDP growth rates are winsorized at the 1st and 99th percentile. Data is obtained from the OECD 


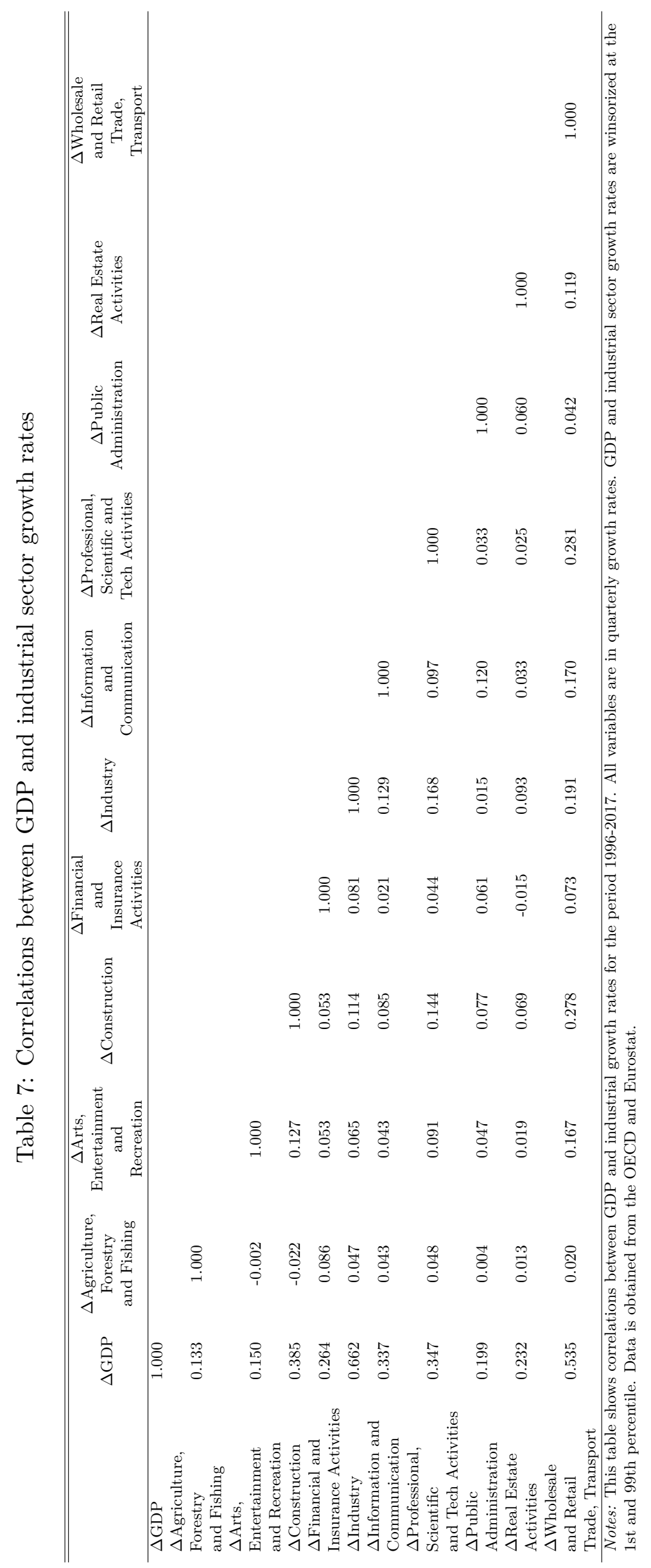


Table 8: Summary statistics of dependent and independent variables

\begin{tabular}{|c|c|c|c|c|c|c|}
\hline & (1) & $(2)$ & (3) & $(4)$ & $(5)$ & (6) \\
\hline & $\mathrm{N}$ & mean & p50 & sd & $\min$ & $\max$ \\
\hline$\Delta \mathrm{GDP}$ & 910 & 0.553 & 0.532 & 0.897 & -2.275 & 4.004 \\
\hline $\begin{array}{l}\Delta \text { Agriculture, Forestry } \\
\text { and Fishing }\end{array}$ & 906 & 0.178 & 0.128 & 5.205 & -19.24 & 19.72 \\
\hline $\begin{array}{l}\Delta \text { Arts, Entertainment } \\
\text { and Recreation }\end{array}$ & 906 & 0.320 & 0.295 & 1.756 & -5.420 & 5.914 \\
\hline$\Delta$ Construction & 906 & 0.279 & 0.296 & 2.468 & -8.088 & 7.895 \\
\hline $\begin{array}{l}\Delta \text { Financial and } \\
\text { Insurance Activities }\end{array}$ & 906 & 0.636 & 0.538 & 3.019 & -9.018 & 10.46 \\
\hline$\Delta$ Industry & 906 & 0.445 & 0.429 & 2.699 & -9.753 & 11.16 \\
\hline $\begin{array}{l}\Delta \text { Information and } \\
\text { Communication }\end{array}$ & 898 & 1.488 & 1.236 & 2.667 & -6.968 & 12.06 \\
\hline $\begin{array}{l}\Delta \text { Professional, Scientific } \\
\text { and Tech Activities }\end{array}$ & 906 & 0.835 & 0.784 & 1.828 & -4.825 & 6.882 \\
\hline$\Delta$ Public Administration & 906 & 0.312 & 0.305 & 0.624 & -1.486 & 2.267 \\
\hline$\Delta$ Real Estate Activities & 906 & 0.405 & 0.336 & 1.089 & -2.785 & 3.901 \\
\hline $\begin{array}{l}\Delta \text { Wholesale and Retail } \\
\text { Trade, Transport }\end{array}$ & 898 & 0.521 & 0.592 & 1.274 & -4.337 & 4.053 \\
\hline$\Delta$ Productivity & 916 & 0.313 & 0.270 & 1.197 & -5.830 & 21.71 \\
\hline $\begin{array}{l}\Delta \text { Credit to Non-Financial } \\
\text { Sector }\end{array}$ & 910 & 0.482 & 0.374 & 1.912 & -9.325 & 28.86 \\
\hline$\Delta$ LabourForce & 910 & 0.202 & 0.179 & 0.533 & -1.650 & 7.990 \\
\hline$\Delta$ Consumer Confidence & 907 & 0.0159 & 0.0413 & 0.562 & -2.327 & 2.274 \\
\hline$\Delta \mathrm{GFCF}$ & 910 & 0.867 & 0.674 & 7.326 & -46.95 & 161.1 \\
\hline$\Delta$ Government Expenditure & 910 & 0.410 & 0.388 & 0.926 & -4.893 & 6.657 \\
\hline $\begin{array}{l}\Delta \text { Euro-to-Dollar } \\
\text { Exchange Rate }\end{array}$ & 910 & 0.000484 & 0.00282 & 0.0490 & -0.116 & 0.118 \\
\hline$\Delta \mathrm{VIX}$ & 910 & -0.00367 & -0.0120 & 0.274 & -0.664 & 1.052 \\
\hline
\end{tabular}

Notes: This table shows summary statistics of dependent and independent variables for the period 1996-2017. All variables are in quarterly growth rates. GDP and industrial sector growth rates are winsorized at the 1st and 99th percentile. See the data description for more information on data sources. 


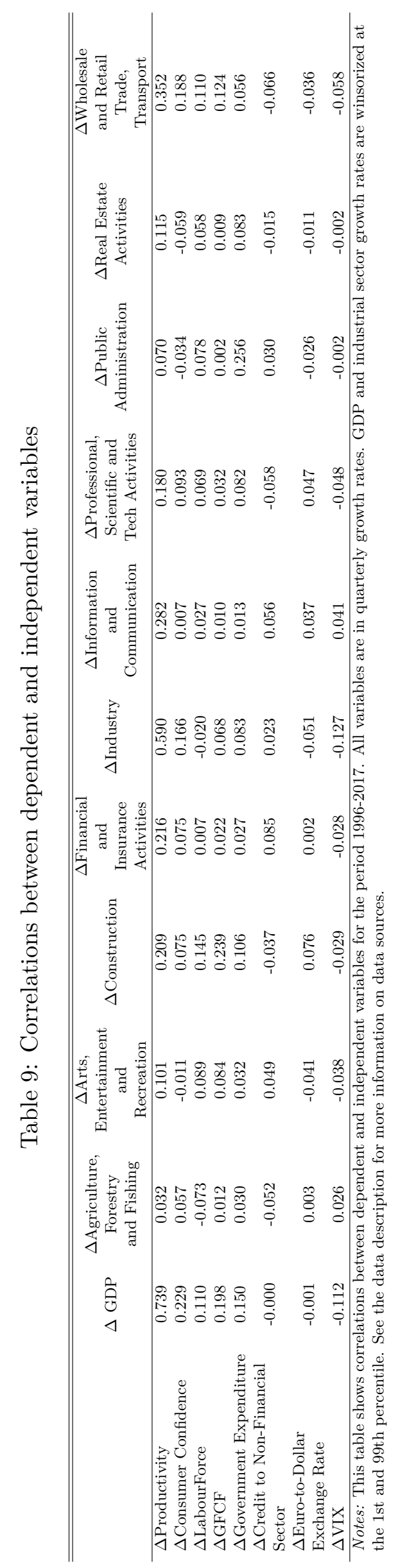


Table 10: Estimation results - Gross domestic product

\begin{tabular}{|c|c|c|c|c|c|c|}
\hline & \multicolumn{2}{|c|}{ no spillovers } & \multicolumn{2}{|c|}{ static spillovers } & \multicolumn{2}{|c|}{ dynamic spillovers } \\
\hline & normal & $\mathrm{t}$ & normal & $\mathrm{t}$ & normal & $\mathrm{t}$ \\
\hline$\rho$ & & & $\begin{array}{r}0.436 \\
(0.026)\end{array}$ & $\begin{array}{r}0.309 \\
(0.032)\end{array}$ & & \\
\hline$\omega$ & & & & & $\begin{array}{r}0.168 \\
(0.102)\end{array}$ & $\begin{array}{r}0.037 \\
(0.034)\end{array}$ \\
\hline$A$ & & & & & $\begin{array}{r}0.007 \\
(0.002)\end{array}$ & $\begin{array}{r}0.042 \\
(0.007)\end{array}$ \\
\hline$B$ & & & & & $\begin{array}{r}0.553 \\
(0.248)\end{array}$ & $\begin{array}{r}0.806 \\
(0.084)\end{array}$ \\
\hline $\ln \left(\sigma^{2}\right)$ & $\begin{array}{r}-0.630 \\
(0.048)\end{array}$ & $\begin{array}{r}-1.388 \\
(0.096)\end{array}$ & $\begin{array}{r}-0.916 \\
(0.048)\end{array}$ & $\begin{array}{r}-1.411 \\
(0.088)\end{array}$ & $\begin{array}{r}-0.922 \\
(0.048)\end{array}$ & $\begin{array}{l}-1.428 \\
(0.087)\end{array}$ \\
\hline constant & $\begin{array}{r}-0.165 \\
(0.029)\end{array}$ & $\begin{array}{r}-0.218 \\
(0.025)\end{array}$ & $\begin{array}{r}-0.135 \\
(0.025)\end{array}$ & $\begin{array}{r}-0.221 \\
(0.023)\end{array}$ & $\begin{array}{r}-0.119 \\
(0.026)\end{array}$ & $\begin{array}{l}-0.219 \\
(0.022)\end{array}$ \\
\hline$\Delta \mathrm{VIX}$ & $\begin{array}{r}-0.002 \\
(0.092)\end{array}$ & $\begin{array}{r}0.165 \\
(0.080)\end{array}$ & $\begin{array}{r}-0.002 \\
(0.080)\end{array}$ & $\begin{array}{r}0.110 \\
(0.070)\end{array}$ & $\begin{array}{r}-0.031 \\
(0.080)\end{array}$ & $\begin{array}{r}0.073 \\
(0.063)\end{array}$ \\
\hline$\Delta$ EuroToDollar & $\begin{array}{r}-0.022 \\
(0.505)\end{array}$ & $\begin{array}{r}1.243 \\
(0.415)\end{array}$ & $\begin{array}{r}0.149 \\
(0.438)\end{array}$ & $\begin{array}{r}0.687 \\
(0.385)\end{array}$ & $\begin{array}{r}0.121 \\
(0.432)\end{array}$ & $\begin{array}{r}1.159 \\
(0.358)\end{array}$ \\
\hline$\Delta$ Productivity & $\begin{array}{r}0.519 \\
(0.022)\end{array}$ & $\begin{array}{r}0.722 \\
(0.026)\end{array}$ & $\begin{array}{r}0.447 \\
(0.020)\end{array}$ & $\begin{array}{r}0.682 \\
(0.025)\end{array}$ & $\begin{array}{r}0.441 \\
(0.020)\end{array}$ & $\begin{array}{r}0.672 \\
(0.025)\end{array}$ \\
\hline$\Delta$ CreditToNonFinancialSector & $\begin{array}{r}-0.118 \\
(0.013)\end{array}$ & $\begin{array}{r}-0.011 \\
(0.012)\end{array}$ & $\begin{array}{r}-0.094 \\
(0.012)\end{array}$ & $\begin{array}{r}-0.018 \\
(0.011)\end{array}$ & $\begin{array}{r}-0.089 \\
(0.012)\end{array}$ & $\begin{array}{r}-0.017 \\
(0.011)\end{array}$ \\
\hline$\Delta$ ConsumerConfidence & $\begin{array}{r}0.273 \\
(0.046)\end{array}$ & $\begin{array}{r}0.160 \\
(0.039)\end{array}$ & $\begin{array}{r}0.117 \\
(0.041)\end{array}$ & $\begin{array}{r}0.104 \\
(0.037)\end{array}$ & $\begin{array}{r}0.114 \\
(0.042)\end{array}$ & $\begin{array}{r}0.117 \\
(0.035)\end{array}$ \\
\hline$\Delta \mathrm{GFCF}$ & $\begin{array}{r}0.008 \\
(0.003)\end{array}$ & $\begin{array}{r}0.004 \\
(0.003)\end{array}$ & $\begin{array}{r}0.005 \\
(0.003)\end{array}$ & $\begin{array}{r}0.004 \\
(0.003)\end{array}$ & $\begin{array}{r}0.005 \\
(0.003)\end{array}$ & $\begin{array}{r}0.004 \\
(0.003)\end{array}$ \\
\hline$\Delta$ LabourForce & $\begin{array}{r}0.136 \\
(0.046)\end{array}$ & $\begin{array}{r}0.146 \\
(0.038)\end{array}$ & $\begin{array}{r}0.090 \\
(0.040)\end{array}$ & $\begin{array}{r}0.120 \\
(0.037)\end{array}$ & $\begin{array}{r}0.086 \\
(0.040)\end{array}$ & $\begin{array}{r}0.108 \\
(0.035)\end{array}$ \\
\hline$\Delta$ GovernmentExpenditure & $\begin{array}{r}0.061 \\
(0.027)\end{array}$ & $\begin{array}{r}0.062 \\
(0.020)\end{array}$ & $\begin{array}{r}0.059 \\
(0.023)\end{array}$ & $\begin{array}{r}0.059 \\
(0.019)\end{array}$ & $\begin{array}{r}0.062 \\
(0.023)\end{array}$ & $\begin{array}{r}0.054 \\
(0.019)\end{array}$ \\
\hline$\nu$ & & $\begin{array}{r}4.122 \\
(0.734) \\
\end{array}$ & & $\begin{array}{r}5.290 \\
(1.029) \\
\end{array}$ & & $\begin{array}{r}5.616 \\
(1.123) \\
\end{array}$ \\
\hline logLik & -971.264 & -812.141 & -862.333 & -774.284 & -854.227 & -761.522 \\
\hline $\mathrm{AICc}$ & 1965.385 & 1649.755 & 1750.139 & 1576.727 & 1739.373 & 1556.797 \\
\hline
\end{tabular}

Notes: This table shows estimation results for different model specifications (no spillovers, static spillovers, dynamic spillovers) based on normal or t-distribution as indicated in the column header. Standard errors are reported in brackets below coefficient estimates. The Akaike information criterion (AICc) is depicted in bold for the model with the best fit (smallest value). The dependent variable is quarterly GDP growth. The sample period spans 1996-2017. All variables are in quarterly growth rates. GDP and industrial sector growth rates are winsorized at the 1st and 99th percentile. See the data description for more information on data sources. 


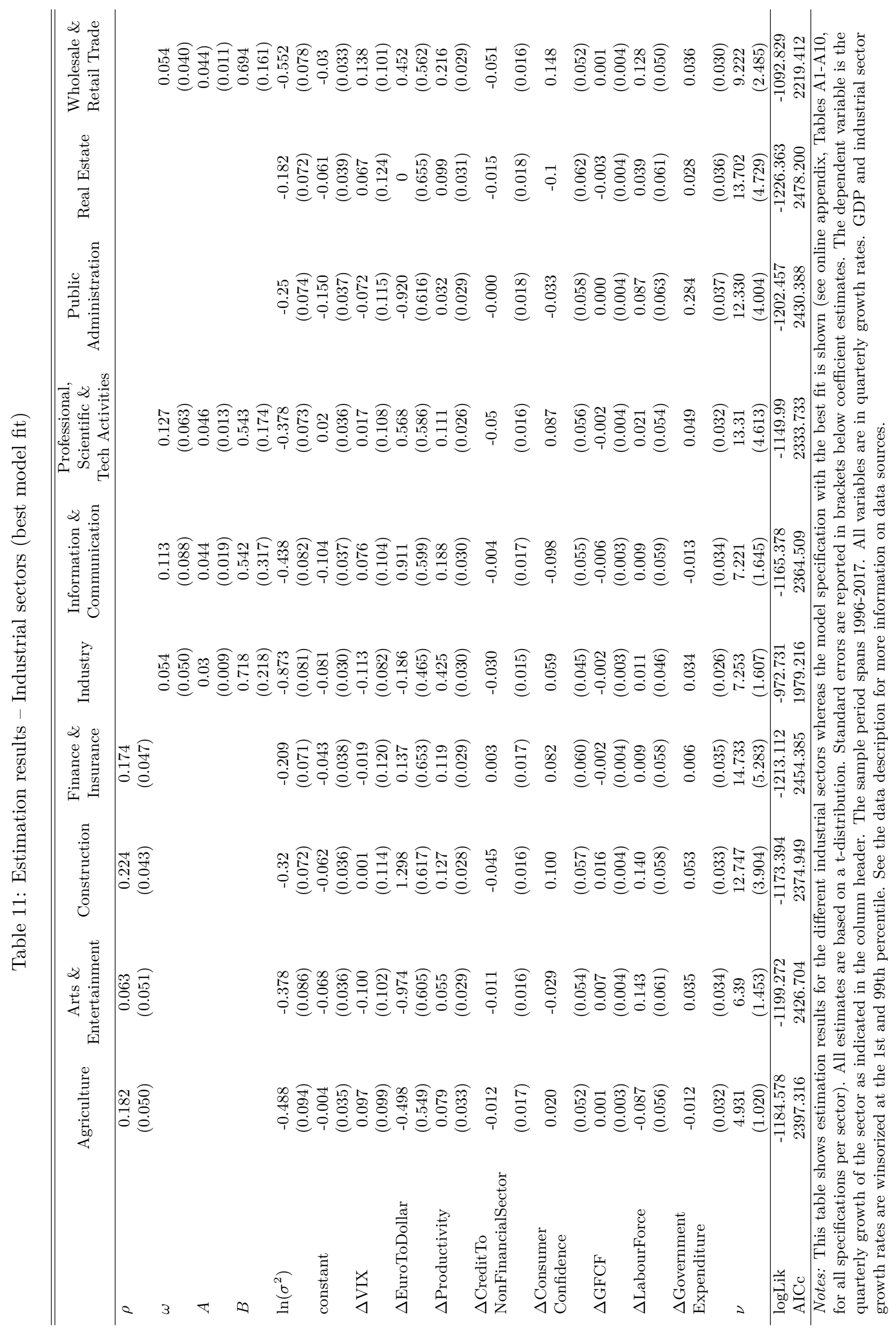


Figure 1: Bilateral banking network, 2017Q4

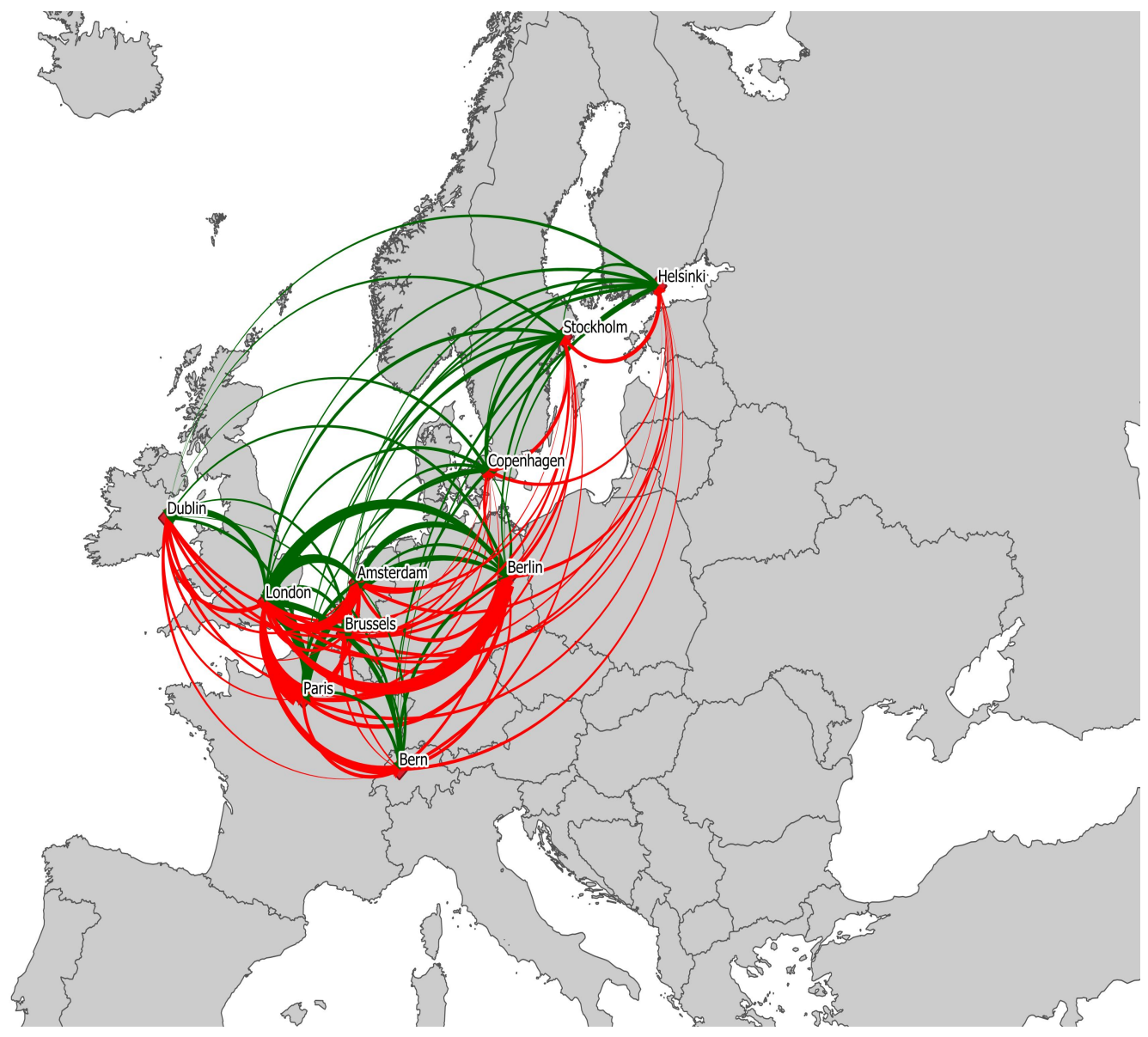

Notes: The graph shows bilateral cross-border claims of countries' banking systems for 2017Q7. Data is obtained from the Locational Banking Statistics of the Bank for International Settlements. 
Figure 2: Growth rates of GDP and all industrial sectors.
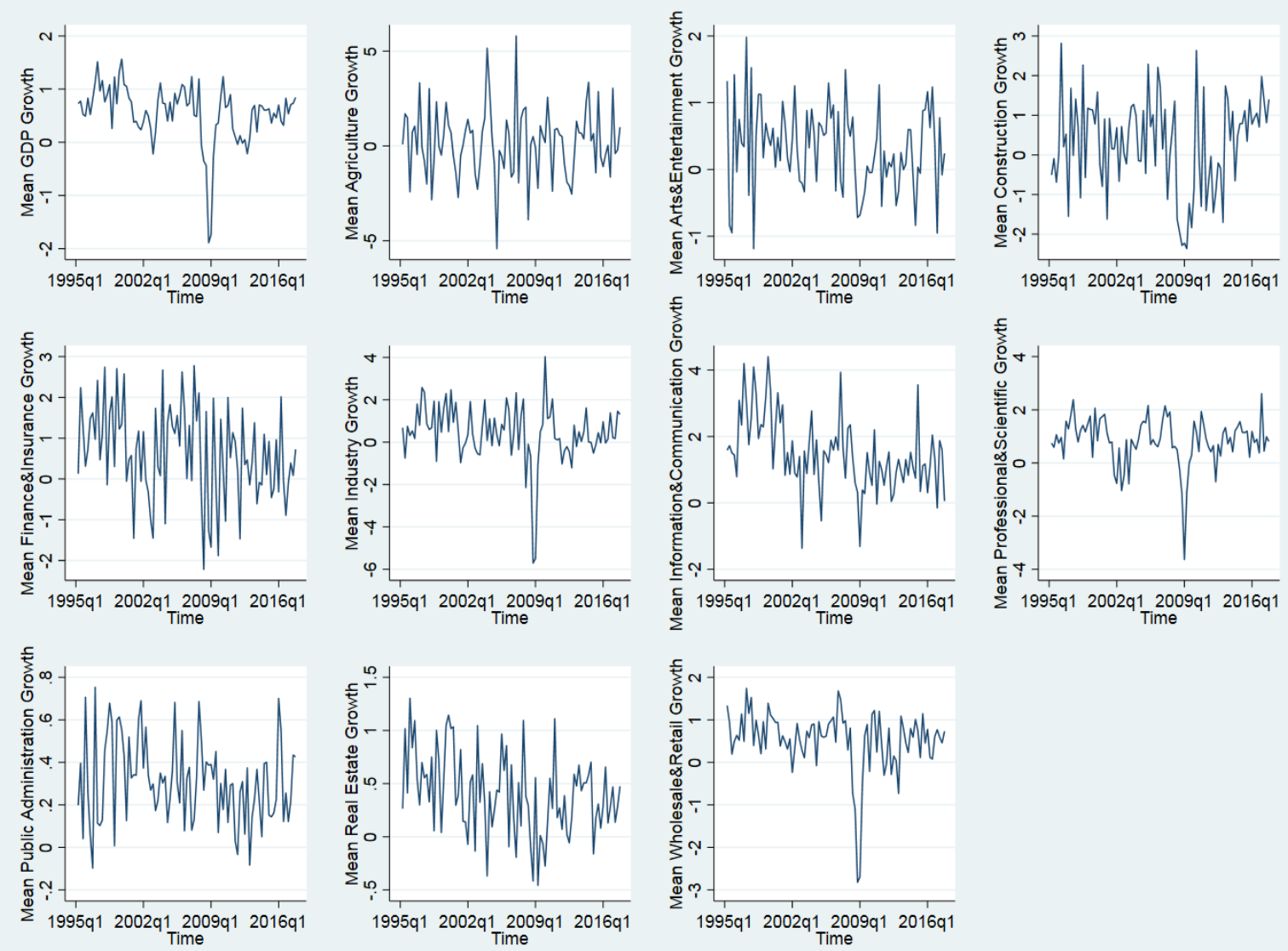

Notes: The graph shows quarterly growth rates of GDP and the industrial sectors. The sample period spans 1996-2017. Data is obtained from the OECD and Eurostat. 
Figure 3: Time-varying spillover strength for gross domestic product

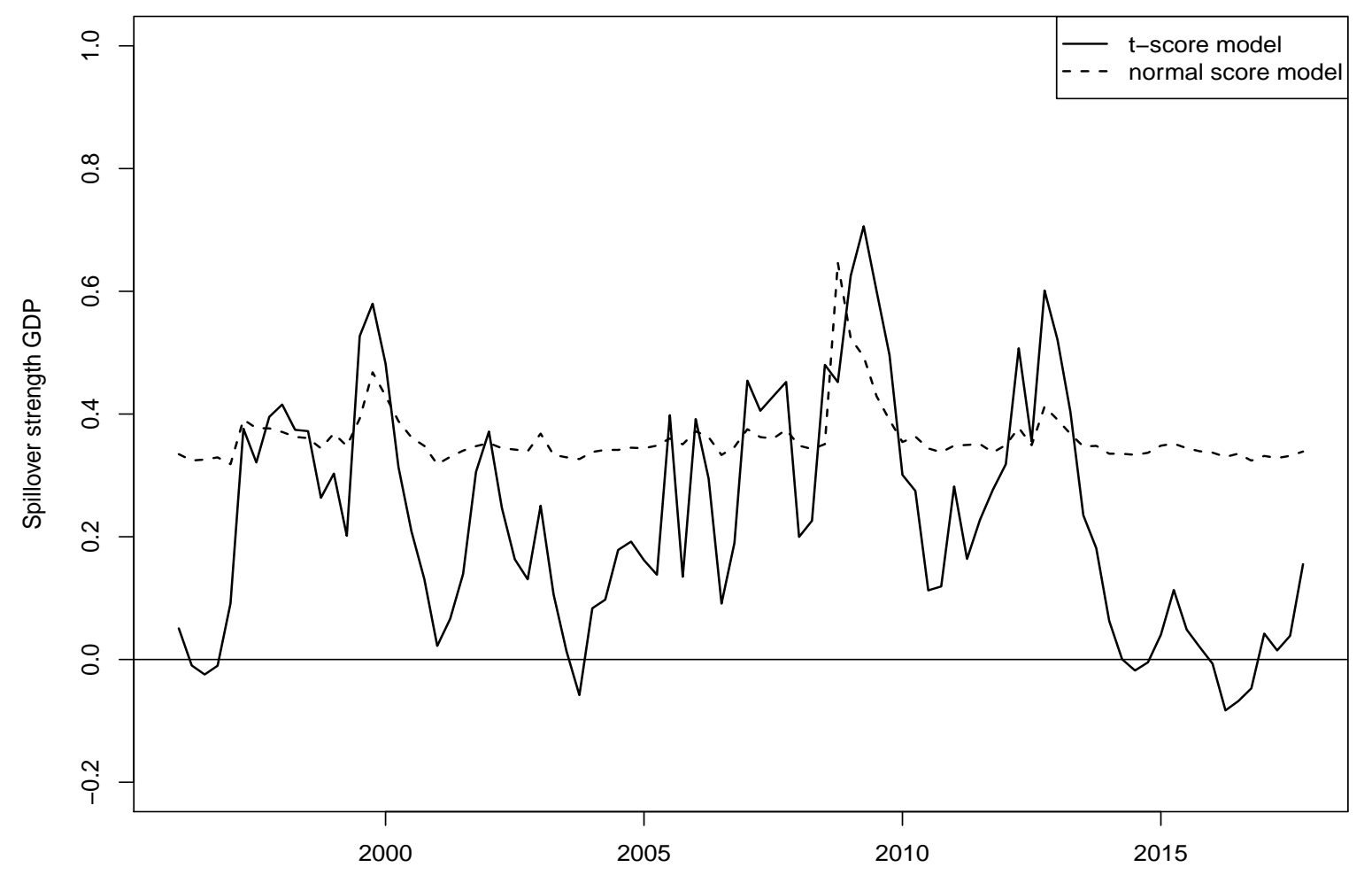

Notes: The graph shows the time-varying spillover strength for the model with quarterly GDP growth as the dependent variable and the sample period 1996-2017. The model is estimated based on a score-driven model with Student's $t$-distributed (solid line) and normally distributed (dashed line) disturbances. 
Figure 4: Time-varying spillover strength for four industrial sectors
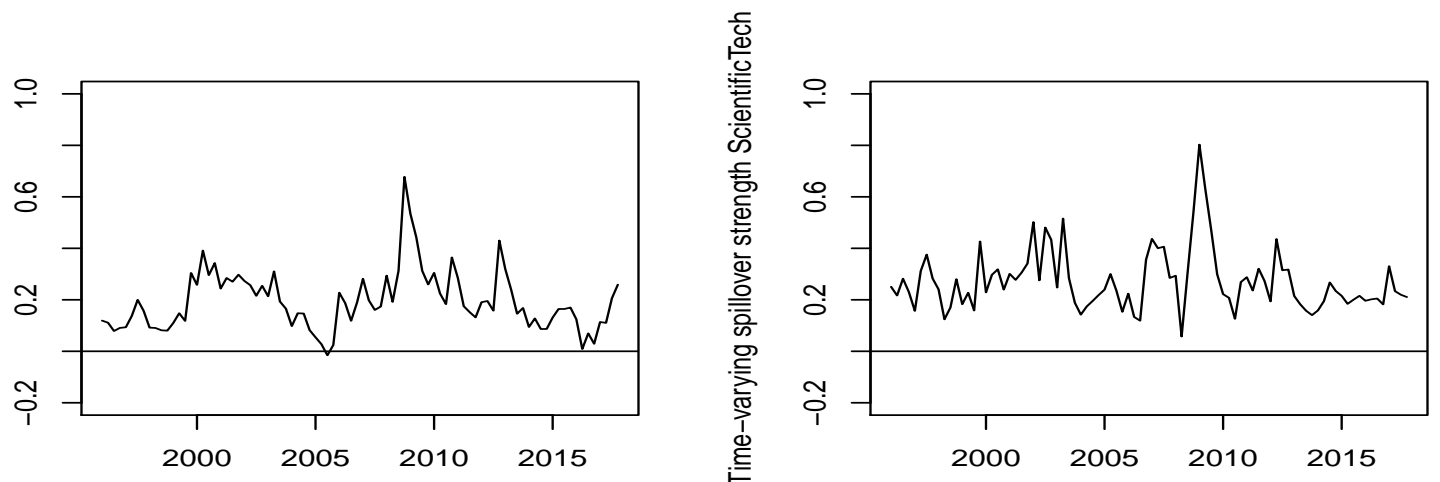

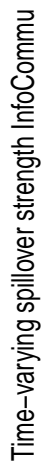
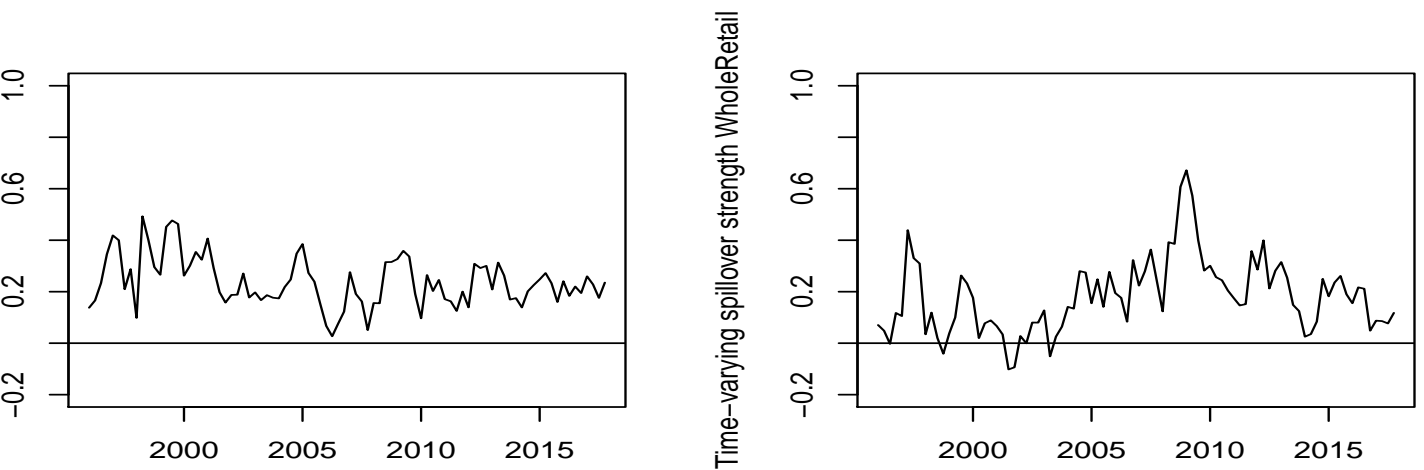

Notes: The graph shows the time-varying spillover strength for the four industrial sectors for which the timevarying model is the best. The dependent variable is the quarterly sectoral growth rate and the sample period spans 1996-2017. The sectors comprise: Upper left: Industry (except construction); Upper right: Professional, scientific and tech activities; Lower left: Information and Communication; Lower right: Wholesale and retail trade, transport, accommodation and food). The model is estimated based on score-driven model with Student's $t$-distributed disturbances. 